\title{
PRELIMINARY OBSERVATIONS ON AI REGULATION
}

\author{
Szerző: \\ Simó Ferenc Zoltán (Dr. Jur.) \\ Debreceni Egyetem
}

A szerző e-mail címe:

simofredz@gmail.com
Lektorok:

Mező Ferenc (PhD)

Eszterházy Károly Egyetem

Borbélyné Bacsó Viktória (PhD)

Medgyessy Ferenc Gimnázium

és Mûvészeti Szakgimnázium

és további két anonim lektor...

\section{Absztrakt \\ ELŐZETES ÉSZREVÉTELEK A MESTERSÉGES INTELLIGENCIA MI) $S Z A B A L Y Y Z A ́ S A R O ́ L$}

Kétség sincs afelől, hogy a technológiai fejlődés megállíthatatlan és afelől sem, hogy a jogalkotók sem tudnak teljes mértékben lépést tartani vele. Azonban mégis szükség van az új technológiák szabályozására és szabályozásuk revíziójára időről időre. Habár, a vizsgálatunk tárgyai a megvalósulás módozati, illetve az eltérő szabályozás lehetősége, amely a normabeli, kulturális/nemzeti különbségeknek/sajátosságoknak és ezek kombinációjának köszönhető.

Kulcsszavak: szabályzás, jog, irányítás, mesterséges intelligencia,

Diszciplínák: jogtudomány, IT, EU tanulmányok

\section{Abstract}

There is no doubt about the fact that the technological progress is unstoppable and not even the law makers can keep up with it wholeheartedly. Still, novel technologies need to be regulated and their regulation aches for revision time after time. Although, the subject of this study is the way how it is to be done, and the possible regulatory differences, owing to different norms in combination with national/cultural differences

Keywords: regulation, law, governance, Artificial Intelligence

Disciplines: Jurisprudence, IT, EU Studies

Simó Ferenc Zoltán (2021): Preliminary Observations on AI Regulation. Mesterséges intelligencia - interdiszciplináris folyóirat, III. évf. 2021/1. szám. 33-59. doi: 10.35406/MI.2021.1.33 
"It is change, continuing change, inevitable change that is the dominant factor in society today. No sensible decision can be made any longer without taking into account not only the world as it is, but the world as it will be...."

(Isaac Asimov)

The distribution and application of new technologies is frequently accompanied with ambiguities as to their long-term (un)intended or unwelcomed impacts, concerning almost all walks of life, including, for instance, law/regulation, privacy or environmental protection and so on. New technologies also pose questions (and a considerable amount of concerns) about the restrictions of the law as the line between injurious/damaging and positive effects is regularly difficult to draw, and even to find. Still, I assume that the necessity to regulate and to revise regulations time after time cannot be questioned, although the way how to do it may differ, due to different norms in combination with cultural differences between countries seem to result in variances in the (practical) enactment, understanding and enforcement, not to mention compliance as well (Compliance is one of the major topics in the European Union but this dissertation will not go into this topic wholeheartedly, but to scratch its surface is unavoidable). It is even more burdensome for scholars to agree on an issue, such as regulation. Ronald Leenes, for instance, argues that "[a]nytime a new technology materializes, or when innovators and entrepreneurs come up with a novel way of doing business, calls for regulatory changes can be heard. These voices do not only come from students and Ph.D. students, who by definition still have a lot to learn, but also from developers, engineers, policymakers, and the odd scientist, who may quickly arrive at the conclusion that there is a regulatory disconnect in need of fixing (Brownsword, 2008). Many people seem to suffer from the Flawed Law Syndrome: the (immediate) urge to call law or regulation outdated or flawed (disconnected) and the desire to fix the problems by addressing the law, rather than using other ways to mend the assumed gaps ('Legal Solutionism)" (Leenes, 2019, 5-6. p.).

Obviously, the "other side", the industry may also complain that the law required to be reformed. Industry typically brings forward two claims concerning the regulatory framework in their own field: first of all, that they are disproportionately constrained and, secondly that the rules are vague or imprecise, two of my primary aims are, first, to discuss why this vagueness may happen, and second, is to relate this ambiguity and elusiveness to novel technologies, such as drones, biometric systems, AI, and so on with the intention to find some practical solutions.

The reaction to make complaints about the regulatory framework seems to be the automatic reaction (of any sides) every time a novel technology appears, rather than exploring the actual state of the art with regard to the technology and the law 
(For instance, in the case of robotics, one can learn more info by: Leenes \& others, 2017). Some scholars argue that the next on the agenda might be robotics, probably, right after, drones, ICT, biometrics, biotechnology, nanotechnologies, and neuroscience-related technologies, since robotics can be considered as a next major broad field of technological improvement that necessitates the attention of regulators (For example: Leenes \& others, 2017). As a matter of fact, the European Parliament, Committee on Legal Affairs drafted its first report with recommendations to the Commission on Civil Law Rules on Robotics on 27 January 2017 /2015/ 2103(INL). What can connect all these forms together is a sense that the technological products demonstrate some level of autonomy in their functioning (The question of autonomy is one of the major motivators of debates concerning AI, robots, or drones as well.), which gives an innovative edge to the interaction between humans and technology; and it is this characteristic, for instance, that makes robotics as a relevant field for regulators and regulation scholars to examine.

Technology and regulation are frequently seen and portrayed as opponents or oppositions. Since technology often symbolizes different kinds of markets, enterprises, and progression, while regulation embodies government, bureaucracy (and its apparatuses), and restrictions to growth and development. Jonathan B. Wiener argues that " $[\mathrm{t}]$ he modern regulatory era, beginning in the 1960 s, has regularly pitted calls to restrain technological risk through regulation against the competing concern that regulation could unduly hobble new technology and progress.

In the 1970s that debate focused on technologies such as nuclear power, supersonic transport, and food additives. Today the debate continues as fears of technologies such as electromagnetic fields, greenhouse gas emissions, and genetically modified foods spark new calls for precautionary regulation (Wiener, 2004, 443. p.).

Also, in the 1980s the so-called space technology started to bloom, and in the 1990s technologies using virtual space started their march (see, for example: Klemens, 2010; to get more on AIs, Maloof, 2017).

In the 1990's the ownership and control of information generated by British science base has been transformed by a combination of regulatory changes designed to promote "the creation of wealth." The Regulation of Science and Technology (Studies in Regulation), edited by Helen Lawton-Smith, offers us a unique set of perspectives on a different regulatory mechanisms set out to achieve this. The contributors use and rely on a large amount of data and analysis to give a critique of political, economic, ethical, technological, and geographical issues connected to the allocation of resources to science and technology, the control and use of the information generated in the context, and the operation of regulatory agencies. 
As a matter of fact we also use telephones/cells, drones biometric systems, robots, AIs, too. Regulation is usually depicted as a single kind of rule or strategy. Jonathan B. Wiener states that "regulation is treated as if it comes in one type and has only one effect on technology, like an engine transmission that can shift into only forward or reverse. In reality, just as there are many different types of technologies (Wiener, J. B., 2004, 443. p. - see also: Bunch \& Hellemans, 2004; or McClellan \& Dorn, 2006), there are many different types of regulations. To name some, different regulatory apparatuses and mechanisms, such as technology requirements, performance standards/criteria, taxes, tradable allowances, and information disclosure, are assumed to have different effects on technological progress, and there might be other important consequences, concerning, for example property or privacy issues.

It is therefore clear that we need to break out of the narrow confines of risk assessment and develop an enlarged framework for thinking about and assessing technology in the context of public policy" (Chapman, 2007, 2. p.). Also, one may pose the question: Is the kind of regulatory tool important? Does it matter? Yes, it is. It does matter, indeed (Wiener, 1999). Technology requirements are supposed to embrace the intention to "force" industry to upgrade or to improve, and might foster the distribution of existing technology throughout the entire sector of industry. But then again, paradoxically, it also have an effect that may discourage or stagnate innovation of novel technologies by (over)specifying a particular technology and promising or guaranteeing no motivations or encouragements for further progresses (Breyer, 1982, 105. p.). Once requirements are authorised, the players of that certain sector have even fewer incentives to invent a better method. The reason is that the government is typically lags behind technology, as compared to industry, and because regulations almost always take years to spread and enforce, the "best technology" authorised by regulation may often be inferior to the best that industry could actually install. To put it simply with no intention to blame either the regulators or the industry/technology, industry and technology, and by implication innovation and invention, do not stop to wait for the cavalry of regulatory forces to arrive, though they do arrive with full forces, which is often not so well-thought of.

Although the recent developments of the issues above may be seen with a future prospective by Harry Armstrong and Jen Rae, they argue that "(...) regulation has struggled to be more future-facing, largely unequipped to cope with more fluid, fast moving technological development, preferring to let markets decide the direction of travel and intervening later as issues begin to surface. Anticipatory regulation helps reframe regulation as a supportive tool for the responsible development and use of new technologies and business models. New and existing 
methods are helping regulators do this in three important ways: Firstly, regulators/regulation can better support innovation as it emerges. Secondly, regulators/regulation can drive innovation directly. Lastly, regulators/regulation can respond faster or act pre-emptively to prevent public harm" (Armstrong \& Rae, 2017). Also, they state that "[a]s technologies create new products and services, and disrupt existing competitive advantage in the global market, creating a dynamic and flexible regulatory environment could secure the industries that will drive growth and create jobs" (Armstrong \& Rae, 2017). Although, some scholars may ask as well: Do novel "smart" technologies such as AI, robotics, smart drones and devices, social media, and automation threaten to disrupt the whole fabric of our society? (Though it seems futuristic, many movies and series have already attempted to answer some repercussion of the introduction of a novel technology, such as an AI. One of the best example is Humans, which is a science fiction tv series that premiered on Channel 4, and was written by the British team Sam Vincent and Jonathan Brackley, based on the Swedish science fiction drama Real Humans, the series focuses on the themes of artificial intelligence and robotics, concentrating on the socio-cultural, and psychological impact of the introduction/invention of anthropomorphic robots called "synths". It includes debates on the right and liability of high-tech AIs, and their legal status as well.) Or does technological innovation hold the potential to reform/transform our democracies, civic societies and legal/regulatory "attitude", creating ones that are more equal and liable or the opposite? Do we need to raise our voices or concerns or does the so-called regulation of technology happen, normatively or otherwise, smoothly? We appear to live an age of never-ending, multifaceted and disruptive technological innovation, one may ponder upon the ideas what, when, and how to structure regulatory interventions. Visibly, to answer these questions have become more and more challenging and for obvious reasons, demanding. Those who attempt to regulate often find themselves in a surrealistic and contradictory situation where they believe they are supposed to decide on either hasty action, for instance, regulations without crucial facts (As it will be shown later in my chapter on drone technology, in that case even the terminology blurred by the lack of consensus. As far as terminology is concerned, drones mainly refer to aerial vehicles, which can fly with no human operator or without any human assistance. However, for regulatory purposes, it should be admitted that many countries and international organizations have already accepted and formed wide-ranging definitions. In general aviation and spacerelated phraseology, a 'drone' usually related to any vehicle that can operate on multiple surfaces and/or in the air without the assistance of a human being on board to control it. Also, a small UAS 
manufacturer has to go through a 3-to-5year process to get hold of a type certificate, which allows the issuance of a standard airworthiness certificate, the small UAS would be technologically outdated and "old-fashioned" by the time it could complete the certification process. For more information, see: Notice of Proposed Rulemaking [NPRM]: DOTFAA, 2015, 9544, 9549.), or reserving to do nothing. Unsurprisingly, in such a case, caution tends to surpass risk. But, I assume, such caution purely functions as a kind of reinforcement of the status quo and it seems that it makes it harder for new technologies to enter the market in time. Though time after time some solution surfaces, one of the solutions might be offered by Mark Fenwick, Wulf A. Kaal and Erik P.M. Vermeulen. In their study, Regulation Tomorrow: What happens when technology is faster than law?, they suggest that law-making and regulatory design need to become more proactive, dynamic and responsive (Fenwick, Kaal \& Vermeulen, 2017). The reformation of the regulatory framework to address escalating and mounting regulatory concerns related to disruptive novel technologies has turned out to be a central issue in the world (See also: Scherer, 2016; or Zetzsche \& others, 2017) (Anne Chapman, for instance, decided to choose to examine the regulation of chemicals, to see why the regulatory system was so ill equipped to address the issues raised by endocrine disruption. She was concerned and felt that treating chemicals as isolated entities became the part of the problem, that was why her research turned out to be an investigation into how we think about and publicly assess technologies, taking synthetic chemicals as her prime example. See: Chapman, 2007).

Preparing a regulatory framework that is supposed to guarantee the safety of both the users and the public at the same time, while assisting the commercial use and consumers' pleasure and satisfaction of a novel technology does not seem to be an easy and stress-free task. Also, the question of how and what to regulate may bring up even more questions and concerns (Butenko \& Larouche, 2015, 52, 72. p.). Nowadays, it seems even more relevant, since innovation is more rapid (similarly to its development) and the global distribution of that technology is much faster, faster than ever before (See, for instance, McGrath, 2013. Or Brownsword \& Somsen, 2009). It is not difficult to imagine that such condition do not really support the burdensome work of regulators, thus it is often observed that regulators find it difficult to keep up with the rapid development of innovation/technology (See Marchant, Allenby \& Herkert (Eds.), 2011) ("Moore's Law notoriously states that the 'functional capacity of ICT products roughly doubles every 18 months', with the same dynamics manifesting in biotechnology, and namely in sequencing human genome. As a result, regulating innovation involves what is called a 'pacing problem' in the academic literature from the US, or the 'challenge of 
regulatory connection' or 'regulatory disconnection' in European-based scholarship." (Butenko \& Larouche, 2015); "The 'pacing problem' generally refers to the situation when technology develops faster than the corresponding regulation, the latter hopelessly falling behind. The metaphor of 'the hare and the turtle' is often brought up as a comparison. As summarized by Marchant and Wallach, 'at the rapid rate of change, emerging technologies leave behind traditional governmental regulatory models and approaches which are plodding along slower today than ever before'." (Butenko \& Larouche, 2015)) (Marchant \& Wallach, 2015).

The view and the justification of the necessity of risk assessment can be linked and supported by Rosario Girasa, who argues that Artificial intelligence (AI) is the state-of-the-art technological (r)evolution which keeps transforming the global economy and can be seen as a key part of the "Fourth Industrial Revolution.(Girasa, 2020, 70-80. p.)" Her book discusses the meaning, types, (sub)fields and applications of AI, as well as U.S. governmental policies and regulations, ethical and privacy issues, predominantly as they relate to and affect facial recognition programs and the Internet-of Things (IoT). There is a lengthy analysis of prejudice, and favourism, AI's effect on the recent and future job market, and how AI triggered fake news. The evident doom of the present regulatory systems/laws, concerning new technologies, is based on the fact that the progress of technology is obviously unstoppable, one may not find a single solution for such a complex and widely debated issue as the regulation of novel technologies without bumping into more and more and newer concerns related to privacy applying all meaning of it. But I need to emphasize the point that my doomsday attitude, regarding the regulation of novel tech, where a drone or an IA, for instance, is just a fine example besides mobile/cell phones or biometrics, I do not mean to argue that law makers are not up to their task, on the contrary. What I really endeavour to highlight is the fact that legal regulations and laws are destined to lag behind because of the inherent nature of the relationship between technology and law. Thus, I may opt for a revisionist (Through my chapters, I intend to use the expressions, such as revision, revisionist, and perfectionist, as my own coinage/tecnicus terminus as I have defined.) regulatory system instead of the existing perfectionist one. In order to avoid being misunderstood, I state that a revisionist method to deal with regulation of novel technologies may not attempt to construct flawless system of laws, since the liaison between law and technology can foreshadow a constant need for revision, as opposed to this, a perfectionist lawmaker feels the need and the urge to create a "perfect" laws and regulatory systems in order to assume to fulfil the traditional/classical ideology based on legal certainty and continuity. Obviously, 
my stand does not mean that we do not need legal certainty and continuity.

"Things do change. The only question is that since things are deteriorating so quickly, will society and man's habit change quickly enough?” - Isaac Asimov

\section{AI: dawn of the human factor - basics and definition(s)}

The first challenge one needs to face is the definition of AIs because even the terms "artificial intelligence" and "intelligent human behaviour" are not welldefined, however. Artificial intelligence designates the work processes of machines that would necessitate intelligence if performed by humans. The term "artificial intelligence" thus means "investigating intelligent problem-solving behaviour and creating intelligent computer systems" (See: Lackes, \& Siepermann, Künstliche Intelligenz) To go even deeper, we need to consider the fact that, at least, two kinds of artificial intelligence can be identified, the so-called weak artificial intelligence when the computer is simply an instrument for studying or probing cognitive processes, and the computer simulates intelligence. The other one is called strong or general artificial intelligence, when the processes in the computer are intellectual, self-learning processes. Computers can comprehend by means of the right software/programming and are able to optimise their own behaviour on the basis of their former behaviour and their experience (see, for exaple: Kerns, 2017). This comprises automatic networking with other machines, which leads to a dramatic scaling effect. It is also important to note that according to European commission "[a]rtificial intelligence (AI) refers to systems that display intelligent behaviour by analysing their environment and taking actions - with some degree of autonomy to achieve specific goals. (Communication from the Commission too the European Parliament...)" .Artificial intelligence and related technologies are altering, forming and reforming both the law and the legal profession. Particularly, technological progresses in fields ranging from machine learning to more cutting-edge robots, including sensors (with hyper sensitivity), virtual realities, algorithms, biometrics (See, for instance, a recent study on the subject: National Academies of Sciences, Engineering), drones, self-driving cars, and more sophisticated "human-like" robots are creating different/novel and formerly unimagined challenges for regulators (One of the best and up-to-date (though bulky) examples: a three-volume research conducted by the National Academies of Sciences, Engineering, and Medicine Hamilton \& others, 2020a; Hamilton \& others, 2020b; Hamilton \& others, 2020c).

Among many others, AI (some of the legal problems and concerns have already been brought up movie makers / writers. For example, A.I. Artificial Intelligence also known as A.I. ) is a 2001 American science fiction drama film directed by Steven Spielberg. The screenplay by 
Spielberg and screen story by Ian Watson were loosely based on the 1969 short story "Super toys Last All Summer Long" by Brian Aldiss. The movie also carries a hint of "The Adventures of Pinocchio, Le avventure di Pinocchio, is a novel for children by Italian author Carlo Collodi, written in Pescia, his work Can be seen as an early example of an AI. It is about the mischievous adventures of an animated marionette named Pinocchio and his father, a poor woodcarver named Geppetto. It was originally published in a serial form as La storia di un burattino in one of the earliest Italian weekly magazines for children, starting from 7 July 1881. All kinds of concerns and issues are brought up by the creators, including the rights of AIs, the regulation on their production, liability for "wrong-doing," privacy issues, and so on.

The European Association for Artificial Intelligence EurAI (formerly ECCAI) was established in July 1982 as a representative body for the European Artificial Intelligence community. Its aim is to promote the study, research and application of Artificial Intelligence in Europe. The next European Conference on AI (ECAI 2020) will take place in Santiago de Compostella. The conference was originally scheduled for June but due to the COVID19 situation it will take place at the end of August and the first week of September. The theme of the conference is "Paving the way towards HumanCentric AI" For more information, visit: https://www.eurai.org/), drones, bio- metric systems and their disruptive capabilities present a conspicuous example for the ability to pose a disruptive potential and regulatory challenges related to such disruption in the existing regulatory framework. AI seems an even more complicated issue because national and international law do not presently recognize $\mathrm{Al}$ as a subject of law, $\mathrm{Al}$ does not have legal personality and as such cannot be held personally liable for damages (Hresko Pearl, 2017). It must be admitted that AI might be able to do much good, including by making products and processes safer, it can raise concerns as well by doing harm. The harm may be both physical and immaterial. The might be as follows, safety and health of individuals, including loss of life, damage to property, intrusion of privacy, limitations to the right of freedom of expression, human dignity, or even discrimination, and can be in connection with a great variety of risks or/and threats (See the works by Isaac Asimov. He has already presented some major issues, concerning robots and AIs.). Evolving combinations of artificial intelligence, big data, and the applications have already been paid substantial attention concerning privacy/confidentiality and other ethical issues. Scholars feel the need to address comprehend these issues systematically and find mechanisms of addressing them that include stakeholders, civil society, to guarantee and safeguard that the benefit(s) of these novel technologies outweigh their disadvantages, or negative impacts. 
Information and communication technologies (ICTs) have long been documented and realized as having significant impacts on social, legal and economic arenas. As a consequence, they often seen as factors that cannot exist without regulatory supervision and, in addition, they call for ethical and social evaluation. Presently, one can observe two intertwining progresses that have the potential to add significantly and critically to the benefits of ICTs but that can also have undesirable effects on ethics and human rights. One of them is an accelerated rate of production and collection of big data, and the other one is novel ways of analysing and using this data. These two have been able to cloud other impacts, such as privacy concerns, not related to data protection. There are several ethical and human/personality rights issues/concerns, such as privacy, loss of employment, consent, identity, dual use, trust, power asymmetries, justice fairness, inequality, autonomy/agency discrimination, security, inclusion and so on (Stahl \& Wright, 2018). Artificial intelligence (AI) and big data analytics are the key technological drivers of what we call "smart information systems" (SIS). Examples of such intelligent sociotechnical systems abound - Google's search engine, Google Translate, Amazon's recommendation system, Amazon's Alexa home assistant, Facebook's likes, smartphones with GPS tracking, predictive policing systems, automated share dealing, healthcare and surgery robots, personal fitness applications, virtual and augmented reality, and many others, ranging from social network data analysis for advertising to traffic data prediction for energy conservation (Stahl \& Wright, 2018). When Stahl, Bernd Carsten Stahl and David Wright have coined the term SIS to point to a novel progress, the technologies elaborated on have a long history, as do some of the ethical questions they can be related to, such as privacy and data protection. A lot of the SIS use personal data, thus protecting such data is therefore an essential step to avoid growing concerns.

Many of the novel features of the European General Data Protection Regulation (GDPR) explicitly address the impact of SIS. Most of the new the novel features relevant to SIS are breach notifications, hefty financial penalties, data protection impact assessments(Privacy Impact Assessment), privacy by design (Privacy by Design Strong Privacy Protection...), and the so-called right to be forgotten (GDPR). Thus, a regulatory framework is supposed to focus on how to minimise the numerous risks of potential harm, particularly, the most noteworthy ones. The main risks associated with the usage of AI concern the application of rules/regulations intended to protect fundamental rights, including personal data and privacy protection and nondiscrimination), as well as safety and those concerns/issues related to and dealing with liability. Nowadays, the question of, 
what an AI is, is often asked by both experts and fans as well. Modern Information Technologies and the dawn of machines/mechanisms power-driven by artificial intelligence (AI) have already had a great influence on the world, including almost all walks of life in the $21 \mathrm{st}$ century (See, for instance, Anderson, Rainie \& Luchsinger, 2018). Workstations, computers, CPUs, algorithms and software make simpler everyday tasks, and it is difficult to envision how most of our life could be succeeded without them. Nevertheless, is it also unmanageable to imagine how most process steps or stages could be accomplished without the human factor? The famous name behind the idea of AI is John McCarthy (Lischka \& McCarthy, 25.10.2011), who began his ground-breaking research on this subject in 1955 and his assumption was that each and every aspect of learning and other domains of intelligence can be described so precisely and accurately that they can be computer-generated or simulated by a machine. Since 1948, McCarthy has been doing researching on artificial intelligence. The term, IA, was actually used by McCarthy in 1955 in a research application written with the legendary computer scientists Claude Shannon, Marvin Minsky and Nathaniel Rochester. The basic assumption of the scientists: "Every aspect of learning and other characteristics of intelligence can in principle be described so precisely that a machine can simulate it." From 1965 to 1980, McCarthy led the Artificial Intelligence Laboratory at
Stanford University. Three years later, in 1958, McCarthy developed the programming language Lisp, an acronym for List Processing, it refers to the structure of the source code of programs written in Lisp, which consists basically of lists. Joseph Weizenbaum programmed his legendary program Eliza in Lisp. Written questions are answered by the software, using natural language, which is considered to be a breakthrough or a revolutionary leap in computer-assisted language processing (Lischka \& McCarthy, 25.10.2011.) The regulation of artificial intelligence can be seen as the expansion of public sector policies and laws for stimulating and regulating artificial intelligence (AI); (Berryhill \& others, 2019)(Barfield, \& Pagallo, 2018) it is therefore related to the broader regulation of algorithms. The regulatory and policy landscape for AI is an emerging issue in jurisdictions globally, including in the European Union (Gesley \& others, 2019) (Report from the Commission to the European Parliament...). Regulation is considered necessary to both encourage $\mathrm{AI}$ and manage associated risks (Buiten, 2019) (Wirtz, Weyerer, \& Geyer, 2019). Regulation of AI through mechanisms such as review boards can also be seen as social means to approach the AI control problem (Sotala \& Yampolskiy, 2014). Some of the possible solutions can be find in an article, titled Solutions to address AI's anticipated negative impacts by Janna Anderson and Lee Rainie. They assume that, as a result of their canvassing offered 
solutions to the troublesome future produced by AI can be the following: first, improving collaboration across borders and stakeholder groups; second, developing policies to assure that development of AI will be directed at augmenting humans and the common good; and third, shifting the priorities of economic, political and education systems to empower individuals to stay ahead in 'the race with the robots' (Anderson \& Rainie, 2018).”

\section{Regulation of AI in the European} Union: Europe as a leader in trustworthy Artificial Intelligence

Europe has everything it needs to become a world leader in Artificial Intelligence (AI) systems that can be safely used and applied. It has outstanding research centres, secure digital systems and a strong position in robotics as well as competitive manufacturing and services sectors, covering almost all walks of life imaginable. The so-called White Paper presented today, presented by the Commission envisions a framework for reliable Artificial Intelligence, based on quality and trust. In partnership with the private and the public sector, the target is to mobilise resources and to create the proper and reasonable drives to accelerate deployment of AI, including by smaller and medium-sized enterprises. This European Union intends to work with its Member States and the research community, to promote, attract and keep talents. Since AI systems can be and are intricate and bear noteworthy risks in certain contexts, such as privacy issues and concerns. Thus, building trust is vital. Clear rules need to address high-risk AI systems without putting too much burden on less risky ones. As always, there are strict EU rules for consumer protection, to address unfair commercial practices and to protect personal data and privacy, are still to be applied. As for high-risk cases, such as in health, policing, privacy, or transport, AI systems are supposed to be transparent, traceable and guarantee human oversight/inaccuracy. As for lower risk AI applications, the Commission envisages a voluntary labelling scheme if they apply higher standards. All AI applications are welcome in the European market as long as they comply with EU rules (White Paper: On Artificial Intelligence...). AS customary in the EU, risk analyses must be done in advance in a company in order to protect employees when they work with robots. Furthermore, the so-called Machinery Directive sets a minimum standard/requirement that all machine products in Europe must meet. The Directive also provides for a manufacturer's risk assessment for any machine. The term machinery is defined as: an assembly, fitted with or intended to be fitted with a drive system other than directly applied human or animal effort, consisting of linked parts, at least one of which moves that are joined together for a specific application. Therefore robots are "machinery" for the purposes of the Directive. The machinery might not be 
operated till a safety briefing concerning the individual workplace of the employee working with the machinery has taken place. It is also suggested to regulate the use of the systems by establishing policies. If technical hitches with the system happen, these incongruities must also be included by the manufacturer of the machinery in its risk assessment. (Directive 2006/42/EC Of The European Parliament)

\section{The White Paper}

In 2017, the European Parliament issued a Resolution calling on the Commission to come up with innovative resolutions centred on civil law that could reply (effectively) to the prompt current development of robotics and AI. The Resolution, with an idea or intention of aiming for the preparation of new tort law concentrating on robots, proposes that a new definition of robot should be prepared. Responding to the Resolution, Paweł Księżak and Sylwia Wojtczak has prepared a study, which is made up of a legal-cognitive-linguistic analysis. It draws three conclusions: the first conclusion is that the definitional method is not the best approach to determining the scope of the regulation of robotics and $\mathrm{AI}$; the second one is that the Resolution is flawed by supposing that a new civil law solution should turn on differentiating between AI and robots and that robots should be treated as central in defining the scope of the regulation; and, lastly, that any new norms should be deep-seated in the concept of AI and not, as suggested and offered by the Resolution, in the concept of robot (Księżak, \& Wojtczak, 2020). According to the European Commission, and the rapid development and progress of Artificial Intelligence cannot be denied. It will have the potential to alter or even revolutionize our lives by improving healthcare, for instance, by making diagnosis more precise, allowing enhanced methods of prevention of illnesses, increasing the efficiency of production systems through predictive maintenance, or by improving the efficiency of other sectors, such as agriculture, environmental protection, or the security sector, and this list may go on.. Simultaneously, The EC argues that Artificial Intelligence (AI) involves numerous potential risks, such as opaque decision-making, gender-based and/or bias or other kinds of discrimination, intrusion in our private lives or, this novel technology can be used for criminal purposes as well. Since global competition has never been so competitive, a firm European approach is required, with bearing in mind the European strategy for AI presented in April 2018 (AI for Europe, COM/2018/237). A working definition can be, though it may be simple that AI can be defined as a collection of technologies that combine data, algorithms and computing power. Progresses in computing and the growing availability of data are therefore strategic drivers of the recent expansion of AI. Europe has the potential to combine its technological and industrial 
assets with a high-grade digital infrastructure and a regulatory framework constructed on its fundamental values and principles to turn into a global leader in innovation in the data economy and its applications as set forth in the European data strategy (Communication from the Commission to the European Parliament...). The White Paper, presented by European Commission in 19 . February, 2020, offers policy alternatives in order to facilitate a dependable and safe improvement of AI in Europe, with respect to the (core) values and rights of EU citizens.

The main building blocks of this White Paper are: "The policy framework setting out measures to align efforts at European, national and regional level. In partnership between the private and the public sector, the aim of the framework is to mobilize resources to achieve an ecosystem of excellence along the entire value chain, starting in research and innovation, and to create the right incentives to accelerate the adoption of solutions based on AI, including by small and medium-sized enterprises (SMEs). The key elements of a future regulatory framework for AI in Europe that will create a unique ecosystem of trust. To do so, it must ensure compliance with EU rules, including the rules protecting fundamental rights and consumers' rights, in particular for AI systems operated in the EU that pose a high risk. Building an ecosystem of trust is a policy objective in itself, and should give citizens the confidence to take up AI applications and give companies and public organisations the legal certainty to innovate using AI.

The Commission strongly supports a human-centric approach based on the Communication on Building Trust in Human-Centric AI8 and will also take into account the input obtained during the piloting phase of the Ethics Guidelines prepared by the High-Level Expert Group on AI" (White Paper: On Artificial Intelligence...). Representing the European Commission President Ursula von der Leyen announced the plan (Shaping Europe's digital future...) at a press conference with the goal is to promote "trust, not fear." The plan also includes measures to update the European Union's 2018 AI strategy (Rabesandratana, 2018) and pump billions into Research and Development over the next decade (Shaping Europe's digital future...).

It can be seen that the EU attempts to come up with a solid and all-inclusive regulatory framework, with no doubts on the probabilities of threats and risks as well. Thus, it not a surprise that The commission requests binding rules for "high-risk" (The EU sticks to its risk-based solutin here as well as in the case of drones.) uses of AI in sectors like health care, transport, or criminal justice. Accordingly, the criteria to determine/define risk may include considerations such as whether it could be harmful to someone, by an AI driven car or a medical device/tool, for instance, or whether a person has little say in whether 
they're affected by an AI's decision, such as when it is used in job recruitment or policing. For high-risk scenarios, the commission intends to put a stop to indecipherable "black box" AIs by demanding human oversight. The rules needs to govern the large data sets used in training AI systems, safeguarding and guaranteeing that they are legally acquired, traceable to their source, and sufficiently broad to train the system. The liability for an AI system's actions is supposed to be dealt with by the law, from both the users' sides and the manufacturers' or designers' sides as well.

As for the high-risk applications have to be presented to be compliant with the rules/regulations before being installed in the European Union. The commission also proposes to offer a "trustworthy AI" certification, to inspire voluntary compliance in low-risk uses. Although EU countries such as Germany have announced plans to install these systems, officials say they often violate EU privacy laws, including special rules for police work (Grüll, 2020). I argue that the new AI strategy is not merely about regulation. The commission may be able to produce an "action plan" for incorporating AI into public services such as public transport and health care, and even more.

The commission is calling for more R\&D, including AI “excellence and testing centres" and a new industrial partnership for AI that could invest billions. Alongside its AI plan, the commission also drawn a separate strategy to encourage data sharing, in part to backing up the development of AI.

\section{Report No. A9-0186/2020 presented by the European Parliament}

The Report observes the necessity of the mutual goal of European Union for a regulatory framework for the progress and expansion, distribution and use of artificial intelligence, robotics and associated/interrelated technologies ('regulatory framework for AI') should allow citizens to share the benefits drawn from their potential, while protecting citizens from the potential risks of such technologies and upholding and supporting the reliability of such technologies in the European Union and elsewhere; that framework should be built on Union law and values and guided by the principles of transparency, fairness, accountability and responsibility, understanding and in accordance with the core values of the European Union.

This regulatory framework is of vital importance in order to avoid the disintegration of the Internal Market, which may result from conflicting and different national legislation. The common regulatory framework can help nurture much needed investment, improve data infrastructure and support research.

Also it should consist of common legal obligations and ethical principles as set out in the proposal for a Regulation. Still, it should be established and be consistent with the improved regulation guidelines. The Union has a strict legal framework in place to guarantee and to safeguard, inter 
alia, the protection of personal data and privacy and non-discrimination, to support and encourage gender equality, environmental protection and consumers' rights; whereas such a legal framework consisting of an extensive body of horizontal and sectoral legislation, as well as the existing rules on product safety and liability, will continue to apply concerning artificial intelligence, robotics and related technologies, though certain adjustments of specific legal instruments may be necessary to reflect the digital transformation and address new challenges posed by the use of artificial intelligence. The report also states that there are (major) concerns that the recent European Union legal framework, including the consumer law and employment and social acquis, data protection legislation, product safety and market surveillance legislation, as well as antidiscrimination legislation may no longer be suitable for purpose to effectively challenge and confront the risks created by artificial intelligence, robotics and related technologies. And, in addition to amendments to current legislation, legal and ethical inquiries with regard to AI technologies ought to be addressed through an effective, comprehensive and future-proof regulatory framework of European Union law reflecting the Union's principles and values as preserved and protected in the Treaties and the Charter of Fundamental Rights that ought to avoid over-regulation, by only closing existing legal gaps, and increase legal certainty/decrease legal uncertainty for businesses and citizens alike, namely by including mandatory measures to prevent practices that would undoubtedly undermine fundamental rights (del Blanco, 8.10.2020). As it is suggested by and can be drawn from this report as well, the existing EU regulatory framework for AI seems to struggle with not having the nature of being "common" (for the purpose of EU harmonization processes) and with being unfit to face the challenges presented by AI.

Needless to say, I assume that can be applied to any novel technologies by implication. AI is set to transform all walks of life, there may not be any segments of society remaining untouched or undisturbed. As a general-purpose technology, its constant development and application will speed up innovation across all dimensions of human enterprise. These changes can both offer remarkable progresses to public welfare and we must not forget that they can create unparalleled public risk as well. Thus, it has been and will be crucial to attempt to minimize that risk, plus, it is vital to comprehend how the progress and application of AI is presently being ruled and overseen. Remodelling or (re)forming the regulatory framework to address accumulating and growing regulatory issues/concerns related to (disruptive or/novel) technologies comes to be more and more essential. Planning or developing a regulatory framework that guarantees the protection of users and the public, while aiding the commercial use and consumer enjoyment of disruptive 
innovation seems even more complex and complicate(Butenko \& Larouche, 2015). This appears "factual" in contemporary settings, where innovation is faster and the global distribution of that technology is much faster (McGrath, 2013; Desilver, 2014).

\section{AI regulation US (Guidance for} Regulation of Artificial Intelligence Applications)

The government of the United States has already taken numerous initiatives to address the growing concern of AI's relationship to national security and its regulation. Among them is the creation of the Defense Innovation Board launched in 2016 with a renewable 2-year mandate whose mission, in part, is to give the Secretary of Defense and other related government officials with advice and recommendations to address future challenges in technology and capabilities (Pellerin, 2016; Ten Commandments of Software...). On February 11, 2019, President Trump signed Executive Order 13859 announcing the American AI Initiative - the United States' national strategy on artificial intelligence. This strategy is a concentrated effort to encourage and protect national AI technology and innovation. The Initiative implements a whole-of-government strategy in collaboration and engagement with the private sector, academia, and the public, and like-minded international partners in agreement with it. It guides the Federal government to follow five pillars for progressing AI: first, invest in AI research and development $(\mathrm{R} \& \mathrm{D})$, the next is to unleash AI resources, third is to eliminate barriers to AI innovation, the penultimate is to educate/train an AIready workforce, and the last is to support an international environment that is supportive of American AI innovation and its responsible use. The U.S. is also supportive to AI tech in order to aid the Federal government work more effectively in its own services and missions in dependable ways.

In February 2020, the White House released the American Artificial Intelligence Initiative: Year One Annual Report. In the year since the AI Executive Order was signed, the Administration called for record amounts of AI R\&D investment, led the development of the first international statement on AI Principles, issued the first-ever strategy for engagement in AI technical standards, published the first-ever reporting of government-wide non-defense AI R\&D spending, and released the first-ever AI regulatory document for the trustworthy development, testing, deployment, and adoption of AI technologies (Maintaining American Leadership...).

Regulation is commonly defined as "the sustained and focused attempt to alter the behaviour of others according to standards or goals, with the intention of producing a broadly identified outcome" (One of the latest views on the subject presented in the form of a case study by Leenders, 2019) (Brownsword, 2017; Brownsword \& 
Somsen, 2009; Moses, 2013). For a regulatory regime to be effective, it needs to have a clear (working) definition of what it regulates. Regrettably, there are numerous different definitions of AI circulating among experts in the field.(Scherer, 2016 for more information on $\mathrm{AI}$ and updates, consult, for example, this website: The Regulation of Artificial Intelligence -A Case Study of the Partnership on AI).

The non-technical definition that is predominant and widespread in the literature on AI policy is that an AI is any digital tool or system that is capable of performing tasks that, if performed by a human, would be said to require intelligence (Brundage \& others, 2018; Scherer, 2016). A vital implication of this definition is that AI is a technology assuming general purpose, the combination of intelligence with computing properties has the possibility to increase productivity across all industries by speeding up invention/innovation (Brundage \& Bryson, 2016)- The repeated importance of AI is powered by the progress of a (wide) range of machine learning (ML) techniques. These techniques are used to create digital systems that can "improve their performance on a given task over time through experience" (Brundage \& others, 2018). A combination of cheaper and enhanced and upgraded computer processing power, access to enormous and organised training datasets, and algorithmic innovation has enabled machine learning academics and professionals to make important innovations in a great variety of domains generally assumed to be key elements of AI (Brundage \& Bryson, 2016; Calo, 2017)-

The risk to public welfare springs from two different forms of AI. The AI literature categorises existing and up-todate ML techniques as "narrow AI", consisting of greatly specialized statistical models that have been trained to match or surpass performance at a human level at a specific task, in a specifically and precisely well-defined environment (Campolo \& Others, 2017). The progress and use of narrow AI is connected with substantial risks concerning personal privacy, bias, inequality and prompt computerisation/ robotics (Brundage \& others, 2018 - to get to know more on limiting technology: Mulligan, 2008). One of the major concerns is definitely connected to the above mentioned personal privacy, which can be said to be greatly linked to (novel) technology as well. However, the mediagenerated doubts/issues/concerns and (great) expectations of AI commonly concern Artificial General Intelligence (AGI). By definition, AGI refers to a system that equals or surpasses human level performance at any task across multiple domains, independent of its training milieu.

Though there is presently no clear progress "line" toward AGI, a survey of AI experts gives a $10 \%$ chance of such AI being developed by 2024, and a 50\% chance of it being developed by 2050 (Grace \& others, 2017; Bostrom, Dafoe \& 
Flynn, 2017). AGI presents public welfare risks on a different order of magnitude, including geopolitical security concerns, labour market dislocations and extreme economic inequality.

Some researchers even identify an existential risk to the survival of our species, if we fail to control or align an AGI with our values (Bostrom, Dafoe \& Flynn, 2017). Other researchers, for example, Katja Grace, John Salvatier, Allan Dafoe, Baobao Zhang and Owain Evans, while analysing the possible impacts and progresses in artificial intelligence (AI), they predict that AI will transform modern life by remodelling transportation, health, science, finance, and the military, and we may add regulation (see: Calo, 2015, 513. p.) and privacy as well. In order to adapt public policy/regulation, it seems essential for us to better anticipate these progresses. They report their findings from a large survey of machine learning researchers on their beliefs about progress in AI. These researchers predict that "AI will outperform humans in many activities in the next ten years, such as translating languages (by 2024), writing high-school essays (by 2026), driving a truck (by 2027), working in retail (by 2031), writing a bestselling book (by 2049), and working as a surgeon (by 2053). Researchers believe there is a $50 \%$ chance of AI outperforming humans in all tasks in 45 years and of automating all human jobs in 120 years, with Asian respondents expecting these dates much sooner than North Americans.
These results will inform discussion amongst researchers and policymakers about anticipating and managing trends in AI" (Grace \& others, 2018).

\section{Conclusion}

This study has only attempted to offer some preliminary observation related to the discussion on the development and application of AI that seem to present unique regulatory challenges. In addition, it looks that the prospect of AGI can create a competitive dynamic that prioritizes the fast development of AI over the safe development of AI.

The dynamic affects the corporations developing AI technology, and the countries tasked with regulating them. Traditional regulatory solutions seem illsuited to the task of minimizing public risk while sustaining innovation. Self-regulation can be identified as an alternative form of governance where an industry designs/creates and puts in force new rules, standards and ethics for themselves, often in "areas where government rules are lacking" (Haufler, 2001, 8-10. p.). I posit that a self-regulatory system has the possibility to be an effective and practical solution to the unique regulatory challenges of AI, and could assist and allow the AI industry to overcome the competitive dynamic that incentivises AI progress/growth haste over safety.

\section{References}

AI for Europe, COM/2018/237 final

Available: 
https:/ /ec.europa.eu/transparency/re gdoc/rep/1/2018/EN/COM-2018237-F1-EN-MAIN-PART-1.PDF [accessed 2 Sep 2020]

Anderson, J. \& Rainie, L. (2018). 2. Solutions to address AI's anticipated negative impacts. Pew Research Center. Available:

https://www.pewresearch.org/interne t/2018/12/10/solutions-to-addressais-anticipated-negative-impacts / [accessed 19 Dec 2020]

Anderson, J., Rainie, L. \& Luchsinger, A. (2018). Artificial Intelligence and the Future of Humans. Pew Research Center.

Available:

https://www.pewresearch.org/interne t/2018/12/10/artificial-intelligenceand-the-future-of-humans / [accessed 19 Dec 2020]

Armstrong, H.\& Rae, J. (2017). A working model for anticipatory regulation. A working paper. Available: https://www.nesta.org.uk/report/aworking-model-for-anticipatoryregulation-a-working-paper/ [accessed 27 Aug 2020]

Barfield, W. \& Pagallo, U. (2018). Research bandbook on the law of artificial intelligence.

Edward Elgar Publishing, Cheltenham.

Berryhill, J. \& others (2019). Hello, World: Artificial Intelligence and its Use in the Public Sector. OECD Working Papers on Public Governance, No. 36,. Available: https://oecdopsi.org/wpcontent/uploads/2019/11/AI-
Report-Online.pdf [accessed $19 \mathrm{Dec}$ 2020]

del Blanco, I. G. (8.10.2020). Report with recommendations to the Commission on a framework of ethical aspects of artificial intelligence, robotics and related technologies (2020/2012(INL)). Committee on Legal Affairs. Available: https://www.europarl.europa.eu/doce o/document/A-9-2020-0186_EN.pdf [accessed 29 Dec 2020]

Bostrom, N., Dafoe, A. \& Flynn, C. (2017). Policy Desiderata in the Development of Superintelligent AI. Future of Humanity Institute. Available: http://governance40.com/wpcontent/uploads/2018/12/aipolicy.pd f [accessed 5 Dec 2020]

Breyer, S. (1982). Regulation and its reform. Harvard University Press, Cambridge, MA. Available: https://www.scienzegiuridiche.unirom a1.it/sites/default/files/docenti/dalbe rti/breyer-regulation-and-itsreform.pdf [accessed 27 Aug 2020]

Brownsword, R. (2008). Rights, Regulation and the Technological Revolution. Oxford University Press, Oxford. DOI 10.1093/acprof:oso/9780199276806.0 01.0001

Brownsword, R. (2017). From Erewhon to AlphaGo: For the sake of human dignity, should we destroy the machines? Law, Innovation and Technology, 9/1, 117-153. DOI 10.1080/17579961.2017.1303927 
Brownsword, R \& Somsen, H. (2009)

Law, Innovation and Technology:

Before We Fast Forward - A Forum

for Debate. Law, Innovation and

Technology, 1/1, 1-73, DOI

10.1080/17579961.2009.11428364 To

link to this article:

https:/ / doi.org/10.1080/17579961.20

09.11428364

Brundage, M. \& Bryson, J. (2016). Smart

Policies for Artificial Intelligence.

ArXiv,

Available: https://arxiv.org/pdf/1608. 08196.pdf [accessed 4 Dec 2020]

Brundage, M. \& others (2018). The

Malicious Use of Artificial Intelligence:

Forecasting, Prevention, and Mitigation.

Future of Humanity Institute,

University of Oxford, Centre for the

Study of Existential Risk, University of

Cambridge, Center for a New

American Security, Electronic Frontier

Foundation. DOI

10.17863/CAM.22520 Available:

https:/ /www.repository.cam.ac.uk/bit stream/handle/1810/275332/1802.07 228.pdf? sequence $=1$ \&is Allowed $=\mathrm{y}$ [accessed 4 Dec 2020]

Buiten, M. C. (2019). Towards Intelligent

Regulation of Artificial Intelligence.

European Journal of Risk

Regulation, 10/1, 41-59. DOI

10.1017/err.2019.8 Available:

https://www.cambridge.org/core/ser vices/aop-cambridge-

core/content/view/AF1AD1940B70

DB88D2B24202EE933F1B/S186729

9X19000084a.pdf/towards_intelligent _regulation_of_artificial_intelligence.p

df [accessed 19 Dec 2020]

Bunch, B. \& Hellemans, A. (2004). The

History of Science and Technology: A

Browser's Guide to the Great Discoveries,

Inventions, and the People Who Made Them

from the Dawn of Time to Today. Mifflin

Company, Houghton. Or McClellan, J.

E. \& Dorn, H. (2006). Science and

Technology in World History. The Johns

Hopkins University Press.

Butenko, A. \& Larouche, P. (2015).

Regulation for Innovativeness or

Regulation of Innovation? Law,

Innovation and Technology, 7/1, 52-82.

DOI 10.1080/17579961.2015.1052643

Calo, R. (2015). Robotics and the lessons of cyberlaw. California Law Review, 103/3, 513-563. DOI

10.2139/ssrn.2402972 Available:

https://29qish1lqx5q2k5d7b491joo-

wpengine.netdna-ssl.com/wp-

content/uploads/2015/07/Calo_Rob

ots-Cyberlaw.pdf [accessed 5 Dec

2020]

Calo, R. (2017). Artificial Intelligence

Policy: A Primer and Roadmap. UC

Davis Law Review, 51/2, 339-435. DOI

10.2139/ssrn.3015350 Available

at: https://lawreview.law.ucdavis.edu/

issues/51/2/Symposium/51-

2_Calo.pdf [accessed 4 Dec 2020]

Campolo, A. \& Others (2017). AI Now

2017 Report. AI Now Institute, New

York. Available:

https://ainowinstitute.org/AI_Now_

2017_Report.pdf [accessed 5 Dec

2020] 
Chapman, A. (2007). Democratizing Technology: Risk, Responsibility and the Regulation of Chemicals, Earthscan Publications, London.

Communication from the Commission too the European Parliament, The European Council, the Council, The European Economic and Social Committee and the Committee of the Regions: Artificial Intelligence for Europe Brussels, 25.4.2018 $\operatorname{COM}(2018) 237$ final Available: https:/ / eur-lex.europa.eu/legalcontent/EN/TXT/PDF/?uri=CELE $\mathrm{X}: 52018 \mathrm{DC} 0237 \&$ from $=\mathrm{EN}$ [accessed 19 Dec 2020]

Communication from the Commission to the European Parliament, the Council, the European Economic and Social Committee and the Committee of the Regions. $\operatorname{COM}(2020) 66$ final Available: https:/ / ec.europa.eu/info/sites/info/ files/communication-europeanstrategy-data-19feb2020_en.pdf [accessed 2 Sep 2020]

Department of Transportation, Federal Aviation Administration [DOT-FAA] (2015). Operation and Certification of Small Unmanned Aircraft System, Federal Register, 80/35. Available: https://www.govinfo.gov/content/pk g/FR-2019-02-13/pdf/201900758.pdf [accessed 25 Mar 2019]

Desilver, D. (2014). Chart of the Week: The Ever-Accelerating Rate of Technology Adoption. Pew Research Center report. available: https:/ /www.pewresearch.org/fact- $\operatorname{tank} / 2014 / 03 / 14 /$ chart-of-the-weekthe-ever-accelerating-rate-oftechnology-adoption/ [accessed 3 Sep 2020]

DIRECTIVE 2006/42/EC OF THE EUROPE AN PARLIAMENT AND OF THE COUNCIL of 17 May 2006 on machinery, and amending Directive 95/16/EC (recast) Available: https://eur-lex.europa.eu/legalcontent/EN/TXT/PDF/?uri=CELE $\mathrm{X}: 32006 \mathrm{~L} 0042 \&$ from $=H U$ [accessed 2 Sep 2020]

A European approach to Artificial intelligence.

Shaping Europe's digital future:

Commission presents strategies for data and Artificial Intelligence: https://digitalstrategy.ec.europa.eu/en/node/159/p rintable/pdf [accessed 19 Dec 2020]

Fenwick, M., Kaal, W. A. \& Vermeulen, E. P. M. (2017). Regulation Tomorrow: What Happens When Technology Is Faster than the Law. American University Business Law Review, 6/3., 561-594.

General Data Protection Regulation. Available: https://gdpr-info.eu/ [accessed 19 Dec 2020]

Gesley, J. \& others (2019). Global Legal

Research Directorate, issuing body. Regulation of Artificial Intelligence in Selected Jurisdictions. Law Library, Library of Congress. LCCN 2019668143 Available: https://www.loc.gov/law/help/artific ial-intelligence/regulation-artificial- 
intelligence.pdf [accessed 19 Dec 2020]

Girasa, R. (2020). Artificial Intelligence as a Disruptive Technology - Economic Transformation and Government Regulation. Palgrave Macmillan. DOI 10.1007/978-3-030-35975-1

Grace, K. \& others (2017). When Will AI Exceed Human Performance? Evidence from AI Experts. Future of Humanity Institute, UK and AI Impacts, Berkeley, USA. Available: https:/ / arxiv.org/abs/1705.08807 [accessed 4 Dec 2020]

Grace, K. \& others (2018). Viewpoint: When Will AI Exceed Human Performance? Evidence from AI Experts. Journal of Artificial Intelligence Research, Vol 62, 729-754. DOI 10.1613/jair.1.11222 Available: https:/ /jair.org/index.php/jair/article /view/11222/26431 [accessed 5 Dec 2020]

Grüll, P. (2020). Germany's plans for automatic facial recognition meet fierce criticism. Euractiv.de. Available: https://www.euractiv.com/section/da ta-protection/news/german-ministersplan-to-expand-automatic-facialrecognition-meets-fierce-criticism/ [accessed 2 Sep 2020]

Guidance for Regulation of Artificial Intelligence Applications https:/ /www.whitehouse.gov/wpcontent/uploads/2020/01/DraftOMB-Memo-on-Regulation-of-AI-17-19.pdf?utm_source=morning_brew [accessed 2 Sep 2020]
Hamilton, B. A. \& others (2020a). Airports and Unmanned Aircraft Systems, Volume 1: Managing and Engaging Stakeholders on AS in the Vicinity of Airports. In National Academies of Sciences, Engineering, and Medicine, The National Academies Press, Washington, DC. DOI 10.17226/25599

Hamilton, B. A. \& others (2020b). Airports and Unmanned Aircraft Systems, Volume 2: Incorporating UAS into Airport Infrastructure Planning Guidebook. In National Academies of Sciences, Engineering, and Medicine, The National Academies Press, Washington, DC. DOI 10.17226/25606

Hamilton, B. A. \& others (2020c). Airports and Unmanned Aircraft Systems, Volume 3: Potential Use of UAS by Airport Operators. In National Academies of Sciences, Engineering, and Medicine, The National Academies Press, Washington, DC. DOI 10.17226/25607

Haufler, V. (2001). A Public Role for the Private Sector: Industry Self-Regulation in a Global Economy. Carnegie Endowment for International Peace, Washington, D.C.Hresko Pearl, T. (2017). Fast \& Furious: The Misregulation of Driverless Cars. New York University Annual Survey of American Law, 73/1, 19-72. Available: https://ttuir.tdl.org/bitstream/handle/2346/734 20/Fast $\% 20 \% 26 \% 20$ Furious $\% 2073 \%$ 20NYU\%20Ann $\% 20$ Sur $\% 20$ Am $\% 20$ 
L\%2019.pdf?sequence $=1$ \&isAllowed $=$ y [accessed 21 Dec 2020]

Kerns, J. (2017). What's the Difference

Between Weak and Strong AI?

machinedesign.com.

https:/ /www.machinedesign.com/mar kets/robotics/article/21835139/whats -the-difference-between-weak-and-

strong-ai or

https://www.internetsociety.org/reso urces/doc/2017/artificial-intelligenceand-machine-learning-policy-

paper/?gclid $=\mathrm{Cj} 0 \mathrm{KCQiA} 5 \mathrm{vb}$

[accessed 19 Dec 2020]

Klemens, G. (2010). The Cell phone: The

History and Technology of the Gadget That

Changed the World. McFarland and

Company, London.

Księżak, P. \& Wojtczak, S. (2020). AI

versus robot: in search of a domain

for the new European civil law. Law,

Innovation and Technology, 12/2, 297-317.

DOI 10.1080/17579961.2020.1815404

Lackes, R. \& Siepermann, M. Künstliche

Intelligenz (KI). In Gabler

Wirtschaftlexikon

http://wirtschaftslexikon.gabler.de/Ar

chiv/74650/kuenstliche-intelligenz-ki-

v12.html [accessed19 Dec 2020]

Leenders, G. (2019). The Regulation of

Artificial Intelligence - A Case Study of

the Partnership on AI, Becoming

Human.https://becominghuman.ai/th

e-regulation-of-artificial-intelligence-a-

case-study-of-the-partnership-on-ai-

c1c22526c19f [accessed 4 Dec 2020]

Leenes, R. (2019). Regulating New

Technologies in Times of Change. In
Reins, L. (Ed.) Regulating New

Technologies in Uncertain Times. Springer,

The Hague. DOI 10.1007/978-94-

6265-279-8_1

Leenes, R. \& others. (2017). Regulatory

challenges of robotics: some guidelines

for addressing legal and ethical issues.

Law, Innovation and Technology, 9/1, 1-

44. DOI

10.1080/17579961.2017.1304921

Available:

https://research.tilburguniversity.edu/ files/23365230/Regulatory_challenges _of_robotics_some_guidelines_for_ad dressing_legal_and_ethical_issues.pdf [accessed 26 Aug 2020]

Lischka, K. \& McCarthy, J. (25.10.2011)

Der Vater der Rechner-Cloud ist tot.

Spiegel Online. Available:

www.spiegel.de/netzwelt/web/john-

mccarthy-der-vater-der-rechner-cloudist-tot-a-793795.html [accessed 14 Dec 2020]

Maintaining American Leadership in Artificial Intelligence. (2019). / Presidential

Documents / Federal Register, 4/31, 3967-3972

https://www.govinfo.gov/content/pk

g/FR-2019-02-14/pdf/2019-

02544.pdf [accessed 2 Sep 2020]

Maloof, M. (2017). Artificial Intelligence: An

Introduction. Georgetown University,

Washington DC. Available:

http:// people.cs.georgetown.edu/ m

aloof/cosc270.f17/cosc270-intro-

handout.pdf [accessed 27 Aug 2020]

Marchant, G. E. \& WALLACH, W.

(2015) Coordinating Technology 
Governance. Issues in Science and

Technology 31/4. Available:

https:/ / issues.org/coordinating-

technology-governance/ [accessed 11

Nov 2020]

Marchant, G. E., Allenby, B. R. \&

Herkert, J. R. (Eds.) (2011). The

Growing Gap Between Emerging

Technologies and Legal-Ethical Oversight:

the Pacing Problem 3. Springer, New

York. DOI 10.1007/978-94-007-1356-

7

McGrath, R. (2013). The Pace of

Technology Adoption is Speeding Up.

Harvard Business Review, Nov. 25.

Available:

https://hbr.org/2013/11/the-pace-

of-technology-adoption-is-speeding-

up [accessed 4 Nov 2018]

Moses, L. B. (2013). How to Think about

Law, Regulation and Technology:

Problems with 'Technology' as a

Regulatory Target. Law, Innovation and

Technology, 5/1, 1-20. DOI

10.5235/17579961.5.1.1 [accessed 4

Dec 2020]

Mulligan, C. M. (2008). Perfect

Enforcement of Law: When to Limit

and When to Use Technology.

Richmond Journal of Law and Technology,

14/4, 1-49. Available:

https://scholarship.richmond.edu/cgi

/viewcontent.cgi?article $=1295 \&$ conte

$\mathrm{xt}=$ jolt [accessed 4 Dec 2020]

National Academies of Sciences,

Engineering, and Medicine. Life-Cycle

Decisions for Biomedical Data: The

Challenge of Forecasting Costs.
Washington, DC: The National

Academies Press. (2020) DOI:

$10.17226 / 25639$.

Pellerin, C. (2016). Defense Innovation Board

Makes Interim Recommendations,

Department Of Defense News, Oct.

5.

https://dod.defense.gov/News/Articl e/Article/965196/defense-innovationboard-makes-

interimrecommendations/ [accessed 2

Sep 2020]

Privacy Impact Assessment (PIA) Good

Practice. CNIL, 2015. Available:

https://www.cnil.fr/sites/default/files

/typo/document/CNIL-PIA-1-

Methodology.pdf [accessed 19 Dec

2020]

Privacy by Design Strong Privacy Protection-

Now, and Well into the Future; A Report

on the State of PbD to the 33rd

International Conference of Data

Protection and Privacy

Commissioners. Information

Commissioner's Office,2008.

Available: https://www.ipc.on.ca/wpcontent/uploads/Resources/PbDRep

ort.pdf [accessed 21 Dec 2020]

Rabesandratana, T. (2018). With $€ 1.5$

billion for artificial intelligence research,

Europe pins hopes on ethics. Science, Apr

25,

https://www.sciencemag.org/news/2

018/04/15-billion-artificial-

intelligence-research-europe-pins-

hopes-ethics [accessed 2 Sep 2020]

The Regulation of Artificial

Intelligence-A Case Study of the 
Partnership on AI

https:/ / nikolanews.ndnsocial.com.hk/

the-regulation-of-artificial-

intelligence $\% \mathrm{E} 2 \% 80 \% 8 \mathrm{~A}$ -

$\% \mathrm{E} 2 \% 80 \% 8 \mathrm{Aa}$-case-study-of-the-

partnership-on-ai/ [accessed 4 Dec 2020]

Report from the Commission to the European

Parliament, the Council and the European

Economic and Social Committee: Report on

the safety and liability implications of

Artificial Intelligence, the Internet of Things

and robotics. European Commission,

Directorate-General for Justice,

Brussels, 2020. Available: https://eur-

lex.europa.eu/legal-

content/EN/TXT/PDF/?uri=CELE

$\mathrm{X}: 52020 \mathrm{DC} 0064 \&$ from $=$ en [accessed

19 Dec 2020

Scherer, M. U. (2016). Regulating

Artificial Intelligence Systems: Risks,

Challenges, Competencies, and

Strategies. Harvard Journal of Law and

Technology 29/2, 353-400. Available:

http://jolt.law.harvard.edu/articles/p

df/v29/29HarvJLTech353.pdf

[accessed 4 Dec 2020]

Shaping Europe's digital future: Commission

presents strategies for data and Artificial

Intelligence.

https:/ /ec.europa.eu/commission/pre

sscorner/detail/en/ip_20_273

[accessed 2 Sep 2020]

Sotala, K. \& Yampolskiy, R. V.

(2014). Responses to catastrophic AGI risk: a survey. Physica Scripta, 90/1.

DOI 10.1088/0031-

8949/90/1/018001 Available: https://iopscience.iop.org/article/10. 1088/0031-8949/90/1/018001/pdf [accessed 19 Dec 2020]

Stahl, B. C. \& Wright, D. (2018). Ethics and Privacy in AI and Big Data: Implementing Responsible Research and Innovation. IEEE Security and Privacy, 16/3, 26-33. DOI 10.1109/MSP.2018.2701164 Available: https://ieeexplore.ieee.org/document /8395078 [accessed 21 Dec 2020]

Ten Commandments of Software: Working

Document, Defense Innovation Board (April 20, 2018), https://media.defense.gov/2018/Apr /22/2001906836/-1/-

1/0/DEFENSEINNOVATIONBO ARD_TEN_COMMANDMENTS_O F_SOFTWARE_2018.04.20.PDF [accessed 2 Sep 2020]

White Paper: On Artificial Intelligence - A European approach to excellence and trust.

For more information, visit: https://ec.europa.eu/info/sites/info/ files/commission-white-paperartificial-intelligence-feb2020_en.pdf [accessed 2 Sep 2020]

Wiener, J. B. (1999). Global environmental regulation: instrument choice in legal context. The Yale Law Journal, 108/4, 677800. DOI $10.2307 / 797394$

Wiener, J. B. (2004). The regulation of technology, and the technology of regulation. In Technology in Society, 26/2, 483-500. Available: https://scholarship.law.duke.edu/facu lty_scholarship/1163/ [accessed 27 Aug 2020] 
Wirtz, B. W., Weyerer, J. C. \& Geyer, C. (2019). Artificial Intelligence and the Public Sector-Applications and Challenges. International Journal of Public Administration, 42/7, 596-615. DOI 10.1080/01900692.2018.1498103

Available:

https://www.tandfonline.com/doi/ab s/10.1080/01900692.2018.1498103

[accessed 19 Dec 2020]

Zetzsche, D. A. \& Others. (2017).

Regulating a Revolution: From

Regulatory Sandboxes to Smart

Regulation. Fordham Journal of Corporate and Financial Law 23/1, 31-104. 